\title{
Chapter 13: Primates from the Baynunah Formation
}

\section{Christopher C. Gilbert ${ }^{1-3}$ and Andrew Hill ${ }^{4}$}

${ }^{1}$ Department of Anthropology, Hunter College of the City University of New York, 695

Park Avenue New York, NY 10065, USA. cgilbert@hunter.cuny.edu

${ }^{2}$ Departments of Anthropology and Biology, the Graduate Center of the City University of New York, 365 Fifth Avenue, NY 10016, USA

${ }^{3}$ New York Consortium in Evolutionary Primatology, New York, NY, USA

${ }^{4}$ Department of Anthropology, Yale University, P.O. Box 208277, New Haven, CT 06520-8277, USA 


\begin{abstract}
Fossil primates of the Baynunah Formation are represented by only two cercopithecoid specimens: AUH 35, a male lower canine of an indeterminate cercopithecid from site JDH-3, and AUH 1321, a lower molar of a guenon from site SHU 2-2. Although rare, these cercopithecoid primates are significant in terms of their age and biogeographic implications. AUH 1321 is the earliest known guenon in the fossil record, and at $\sim 8-6.5 \mathrm{Ma}$, it is also one of the earliest cercopithecines known. The age and geographic position of both specimens in the Arabian Peninsula supports late Miocene Eurasian dispersal scenarios for cercopithecoid primates out of Africa and through Arabia before the Messinian Crisis. Whether or not this dispersal included both cercopithecines (macaques) and colobines is unclear, and it remains possible that both groups also dispersed across the Mediterranean Basin or Straits of Gibraltar during the Messinian as well. Among the potential Arabian dispersal routes, there is perhaps some support for the southern path over the Straits of Bab el Mandeb based on the presence of $\sim 8-5.5$ Ma cercopithecine and colobine fossils in the East African fossil record, geographically close to the Horn of Africa.
\end{abstract}

Running head: Primates 


\section{Introduction}

Although rare, the cercopithecoid monkeys of the Baynunah Formation are significant members of the fauna, providing key insights into the evolution and dispersal of this highly successful group of primates. To date, two specimens are known: AUH 35, found in early 1989 at Jebel Dhanna 3 (JD-3 or JDH-3, now lost to development), and AUH 1321, a lower molar discovered in early 2009 at site SHU 2-2 on the island of Shuwaihat (Hill and Gundling 1999; Gilbert et al. 2014; see Fig. 13.1).

\section{INSERT FIGURE 13.1 APPROXIMATELY HERE, 1.5 COLUMN WIDTH}

AUH 35 is a lower left canine (Fig. 13.2a) described by Hill and Gundling (1999) as a male cercopithecid with uncertain affinities to either of the major extant subfamilies: Cercopithecinae and Colobinae. Hill and Gundling (1999) provided a bivariate plot of canine height vs. mesiodistal length, which demonstrated that extant male and female cercopithecoid canines could be easily distinguished, but colobine and cercopithecine canines could not. AUH 1321, on the other hand, is a lower left molar, most likely an $\mathrm{M}_{1}$, with clear affinities to the subfamily Cercopithecinae based on its relatively high crown and low cusp height, among other features (Fig. 13.2b). For full descriptions of AUH 35 and AUH 1321, see Hill and Gundling (1999) and Gilbert et al. (2014).

\section{INSERT FIGURE 13.2 APPROXIMATELY HERE, 1.5 COLUMN WIDTH}

\section{AUH 1321: An early guenon}

While the cercopithecine affinities of AUH 1321 are clear, its taxonomic affinities beyond the subfamily level are not immediately obvious. Gilbert et al. (2014) suggested that the specimen is most likely a member of the tribe Cercopithecini, more commonly known as 
'guenons', whose previously known distribution was restricted to continental Africa and whose fossil record was previously restricted to the Plio-Pleistocene.

Given its relatively narrow shape (maximum mesiodistal length relative to buccolingual width) and small size, it is conceivable that the specimen represents a $\mathrm{dP}_{4}$ rather than an $\mathrm{M}_{1}$. To fully investigate this possibility, we performed qualitative and quantitative comparative analyses of cercopithecine $\mathrm{dP}_{4} \mathrm{~s}$ and $\mathrm{M}_{1} \mathrm{~s}$ to evaluate the most likely attribution of AUH 1321 (see also Gilbert et al., 2014). We restricted ourselves to an extant comparative sample consisting of macaques and guenons because these taxa share both similar size and general dental features with AUH 1321. Macaques, in particular, are known from the late Miocene of North Africa and Europe (e.g., see Biogeography section below), and so a reasonable alternative hypothesis is that $\mathrm{AUH} 1321$ represents a macaque $\mathrm{dP}_{4}$ or $\mathrm{M}_{1}$ rather than a guenon.

The results of our qualitative and quantitative comparisons of macaque and guenon $\mathrm{dP}_{4}$ and $\mathrm{M}_{1}$ crown and root morphology demonstrate that AUH 1321 is almost certainly a guenon $\mathrm{M}_{1}$ and not a macaque $\mathrm{M}_{1}$ or $\mathrm{dP}_{4}$ (Figs. 13.3-13.4). Typical cercopithecine $\mathrm{dP}_{4} \mathrm{~s}$ are characterized by a high degree of basal crown flare as well as a proximal root that is constricted underneath the crown, leading to clear enamel "bulging" at the base of the crown on the buccal and lingual sides (Fig. 13.3). Typical guenon $\mathrm{M}_{1}$ s, on the other hand, do not exhibit a high degree of flare and are straight-sided at the base of the crown, with robust proximal roots that do not display any obvious constriction (Fig. 13.3). Furthermore, $\mathrm{dP}_{4} \mathrm{~s}$ exhibiting similar levels of crown wear as seen in AUH 1321 typically demonstrate clear root absorption on the lingual side of the tooth, a feature not found in AUH 1321 itself. Instead, the distal root of AUH 1321 is either slightly broken (most likely) or exhibits a slightly open apex (less likely) and would have been even longer than preserved, again most consistent 
with a permanent molar rather than a deciduous premolar (Fig. 13.3). Even though the distal root of AUH 1321 displays a bit of distal flare, similar levels of distal flare can also be found among a small sample of extant guenon $\mathrm{M}_{1} \mathrm{~s}$ (Fig. 13.3).

Discriminant function analyses (DFA) were also performed on a sample of 43 guenon $\mathrm{M}_{1} \mathrm{~s}, 11$ guenon $\mathrm{dP}_{4} \mathrm{~s}, 30$ macaque $\mathrm{M}_{1} \mathrm{~s}$, and 8 macaque $\mathrm{dP}_{4} \mathrm{~s}$ collected from the American Museum of Natural History (AMNH) and US Smithsonian National Museum of Natural History (USNM), including both wild-shot and nonpathological zoo specimens to maximize sample sizes. Prior probabilities were calculated from actual group sample sizes (rather than assuming equal sample sizes) and leave-one-out classification was used as a measure of cross-validation. In order to determine its probable group membership, AUH 1321 was excluded from the calculation of any discriminant functions and then classified post-hoc as an "unknown". Five crown and root shape variables were included in the analyses: (i) mesiodistal crown length/mesial buccolingual crown breadth, (ii) mesiodistal crown length/distal buccolingual crown breadth, (iii) mesial buccolingual crown breadth/distal buccolingual crown breadth, (iv) distal root apex breadth/mesiodistal crown length, and (v) distal root + crown height (total distal height)/mesiodistal crown length. Results are presented in Figure 13.4.

The first DFA concentrated on discriminating macaque and guenon $\mathrm{dP}_{4} \mathrm{~s}$ from $\mathrm{M}_{1} \mathrm{~s}$. $94.6 \%$ (88\% cross-validated) of specimens were correctly classified as either $\mathrm{M}_{1} \mathrm{~s}$ or $\mathrm{dP}_{4} \mathrm{~S}$ (Fig. 13.4a). The indices with the highest loading on discriminant function 1 are root height (v) and crown shape (i and ii), indicating that $\mathrm{dP}_{4} \mathrm{~s}$ are most easily distinguished from $\mathrm{M}_{1} \mathrm{~S}$ by their shorter roots and narrower crowns. Note that AUH 1321 plots well within the $\mathrm{M}_{1}$ range (and outside the $\mathrm{dP}_{4}$ range) on discriminant function 1 and is classified as an $\mathrm{M}_{1}$ with a posterior probability of $99.2 \%$ (Fig. 13.4a). A second DFA of guenon and macaque teeth 
attempted to discriminate among guenon $\mathrm{M}_{1} \mathrm{~s}$, guenon $\mathrm{dP}_{4} \mathrm{~s}$, macaque $\mathrm{M}_{1} \mathrm{~s}$, and macaque $\mathrm{dP}_{4}$ s. $79.3 \%$ (73.9\% cross-validated) of specimens were correctly classified into these four groups. The indices with the highest loading on discriminant function 1 are overall narrowness of the crown (i), width of the distal lophid compared with the mesial lophid (iii), and root height $(\mathrm{v})$. The index with the highest loading on discriminant function 2 is distal root breadth (iv). AUH 1321 plots well within the range of guenon $\mathrm{M}_{1}$ s (blue minimum convex polygon), outside the range of macaque $\mathrm{M}_{1} \mathrm{~s}$ (purple minimum convex polygon), and well outside the range of guenon $\mathrm{dP}_{4} \mathrm{~S}$ and macaque $\mathrm{dP}_{4} \mathrm{~S}$ (Fig. 13.4b). AUH 1321 is classified as a guenon $\mathrm{M}_{1}$ with a posterior probability of $97.5 \%$. In sum, although there is overlap between AUH 1321 and some cercopithecine $\mathrm{dP}_{4} \mathrm{~s}$ in certain features, there is no $\mathrm{dP}_{4}$ in our sample that has all of the characteristics found in AUH 1321, and this specimen is considered to be a guenon $\mathrm{M}_{1}$ with a high degree of probability.

INSERT FIGURE 13.3 APPROXIMATELY HERE, 1.5 COLUMN WIDTH

INSERT FIGURE 13.4 APPROXIMATELY HERE, 1.5 COLUMN WIDTH

INSERT TABLE 13.1 APPROXIMATELY HERE, 2 COLUMN WIDTH

The age of the Baynunah Formation, which encompasses both JDH-3 and SHU 2-2, is currently estimated at between $8 \mathrm{Ma}$ and $6 \mathrm{Ma}$ on the basis of biochronological comparisons. The most probable age is suggested to be around 7 Ma (Hill 1999; Bibi et al. 2006, 2013, this volume; Hill et al. 2012; Gilbert et al. 2014; Peppe et al. this volume). The earliest known cercopithecid fossils are found in the Kabasero section of the Ngorora Formation, Kenya, dated to $\sim 12.5 \mathrm{Ma}$; these specimens most likely represent early colobines (Benefit 
and Pickford 1986; Rossie et al. 2013). Specimens attributable to the subfamily Cercopithecinae, however, are first known from isolated and fragmentary dental material from 8.0 Ma deposits in the Chorora Formation of Ethiopia (Suwa et al. 2015). More complete and taxonomically diagnosable cercopithecine material is represented by Parapapio lothagamensis from the Upper or Lower Members of the Nawata Formation, Lothagam, Kenya, 7.4-5.5 Ma (Leakey et al. 2003; McDougall and Feibel 2003). Thus, the estimated age for AUH 1321 in the Baynunah Formation rivals that of other early cercopithecines at Chorora and Lothagam. Furthermore, AUH 1321 is the earliest representative of the tribe Cercopithecini by at least 2.3 million years (Plavcan et al. 2013), making it both biogeographically and chronologically significant.

\section{Taxonomic affinities of AUH 35}

Given the clear presence of a small cercopithecine at SHU 2-2, we decided to re-analyze AUH 35 in an attempt to clarify its taxonomic affinities. We conducted a multivariate analysis of male cercopithecoid canines to determine if an increased number of size and shape variables could more successfully separate colobine and cercopithecine specimens. Data for extant and fossil cercopithecine and colobine canines were taken from the online PRIMO database (PRImate MOrphology database, access courtesy of Eric Delson) and resulted in a total sample of 219 cercopithecine and 77 colobine canines preserving three raw measurements comparable with those of AUH 35: crown height, crown width, and crown length (data set provided in the Appendix). From these three measurements, a total volume of the canine was calculated (modeled as a pyramid...[length $\mathrm{x}$ width $\mathrm{x}$ height]/3) as an overall measure of canine size. Each raw measurement was then divided by the cube root of canine volume to maintain similar units, resulting in three ratios: relative crown height, rel- 
ative crown width, and relative crown length. Three additional shape ratios were also created: crown height/crown width, crown height/crown length, and crown length/crown width. These six ratios plus the cube root of canine volume ( 7 total measurements) were included in a discriminant function analysis in SPSS v.23.0.0.2 to determine how well they distinguish between cercopithecine and colobine canines. Prior probabilities were calculated from group size rather than assuming equal groups, and leave-one-out classification was used as a measure of cross-validation and robusticity of the results. AUH 35 was excluded from the calculation of the discriminant function and then included as an "unknown" to calculate its probable group membership. Because many isolated fossil canines are assigned as male or female on the basis of size alone, we ran the analysis two ways: first with all of the extant and fossil specimens together and then with only extant specimens of known and confirmed sex (161 cercopithecine males and 71 colobine males).

Results of our analysis suggest that canines can reliably be identified to subfamily in many cases. Overall, $84.1 \%$ of specimens were correctly classified to subfamily in the extant + fossil analysis (83.4\% cross-validated), and over $90 \%$ of cercopithecines, in particular, were correctly classified. However, colobine canines were misclassified over one-third of the time (38\%), and as Figure 13.5a demonstrates, there is substantial overlap between colobine and cercopithecine values on the Discriminant Function. Furthermore, the variable most highly correlated with the Discriminant Function is size (i.e., cube root volume, $r=0.778$ ), suggesting that cercopithecines are being correctly classified at a higher rate because they also represent many of the largest specimens in the sample. Relative canine length $(r=-0.606)$, canine height/canine length $(r=0.565)$, and canine length/canine width ( $r=-0.517)$ also contribute to Function 1, perhaps suggesting shape variables worthy of more sophisticated analyses in the future. Although AUH 35 is classified as a cercopithecine with $77.4 \%$ posterior probability, it regrettably falls in the area of overlap between colobine 
and cercopithecine values (Fig. 13.5a), making any confident attribution to subfamily difficult. The results of the extant-only discriminant analysis were extremely similar, with $89.2 \%$ of canines correctly identified to subfamily ( $88.8 \%$ cross-validated) and similar correlations driving the Discriminant Function (cube root volume, $r=0.683$, canine height/canine length $r=0.607$, relative canine length $r=-0.603$, canine length/canine width $r=-0.479$ ), suggesting that the addition of the fossil specimens did not alter the results. Again AUH 35 was considered most likely to be a cercopithecine (72.8\% posterior probability), but again fell in the area of overlap between cercopithecine and colobine specimens (Fig. 13.5b). Thus, AUH 35 remains an indeterminate cercopithecid at this time.

\section{INSERT FIGURE 13.5 APPROXIMATELY HERE, 1.5 COLUMN WIDTH}

\section{Biogeographic Implications}

While only two fossil primate specimens are currently known from the Baynunah Formation, it seems quite likely that primates are being undersampled, even if the precise bias is unknown (e.g., taphonomic, collection method, or other). The associated Baynunah Formation fauna, along with the reconstructed paleoenvironment, suggests a diverse ecological system including the presence of rivers, woodlands, grasslands, and even deserts (Friend 1999; Whybrow and Hill 1999; Bibi et al. this volume). Such environments in Africa often support multiple cercopithecoid taxa, both colobines and cercopithecines, making it possible that the Arabian Peninsula was a viable dispersal route for monkeys during the late Miocene.

Although there is no evidence that guenons ever dispersed beyond the Arabian Peninsula, it is quite clear that both papionins and colobines did. The first macaques appear 
in Europe in the latest Miocene -6.0-5.3 Ma and in Asia by the early Pliocene (Delson 1980, 1996; Delson et al. 2000; Kohler et al. 2000; Alba et al. 2014). Colobines, particularly the genus Mesopithecus, first appear in Eurasia even earlier, by at least $\sim 8.5 \mathrm{Ma}$ in Greece and 7.5 Ma in southwestern and southern Asia (Delson 1994; Harrison and Delson 2007; Ji et al. 2013; Koufos 2013; Alba et al. 2015). The appearance of Macaca in Europe (Italy and the Iberian Peninsula) occurs just after the Messinian Crisis (Alba et al. 2014), whereas Mesopithecus is found across Eurasia $\sim 1-2.5$ million years earlier. Thus, while the dispersal of Macaca into Eurasia could have taken place over the dried up Mediterranean Basin or Straits of Gibraltar during the Messinian Crisis (e.g., Delson 1975; Gautier et al. 1994; Clauzon et al. 1996; Krijgsman et al. 1999; McKenzie 1999; Sierro et al. 1999; Van Couvering et al. 2000; Kohler et al. 2000; Lourens et al. 2004; Rouchy and Caruso 2006; Gibert et al. 2013; Alba et al. 2014), colobines (represented by Mesopithecus) clearly dispersed out of Africa before such a route was available (Fig. 13.6). In our view, the presence of similaraged cercopithecoid monkey fossils in the late Miocene of the Arabian Peninsula supports an Arabian route as the most likely scenario for early cercopithecoid dispersal into Eurasia, perhaps in addition to a later Messinian-induced event over the Mediterranean Basin (Gilbert et al. 2014). As the only late Miocene fossil monkeys known between Africa and Eurasia, the geographic position of the Baynunah cercopithecoids is intriguing, at the very least.

While AUH 35 from JD-3 could represent the same taxon as AUH 1321 purely on size grounds (Gilbert et al., 2014), it is also quite possible that it represents a different cercopithecoid species. In fact, as the analyses here and the previous analysis of Hill and Gundling (1999) suggest, it is entirely possible that AUH 35 represents a fossil colobine; it is within the size and shape range of both colobine (including Mesopithecus) and cercopithecine taxa (see also Gilbert et al. 2014). Interestingly, both colobines and cercopithecines are repre- 
sented in $\sim 8.0$ Ma deposits of the Chorora Formation, Ethiopia (Suwa et al. 2015), and the location of Chorora near the Horn of Africa perhaps further supports a southern dispersal route over the Arabian Straits of Bab el Mandeb before 6.5 Ma as a viable scenario (see dispersal route 3 in Fig. 13.6; see also Bosworth et al. 2005; Gilbert et al. 2014). Unfortunately, the Chorora cercopithecine material is too fragmentary for direct comparison to AUH 1321, but there is one lower canine, CHO-BT 123 , that is broadly similar in length and width dimensions to AUH 35 (see Appendix; Suwa et al., 2015). However, the crown of this specimen is broken such that crown height cannot be measured, so exactly how similar this specimen is to AUH 35 in overall size and shape remains unclear. Other late Miocene canines attributed to male specimens of Pp. lothagamensis at Lothagam and Paracolobus enkorikae at Lemudong'o are also similar in length and width dimensions to AUH 35, although height dimensions are again unavailable (see Appendix; Leakey et al., 2003; Hlusko, 2007). In the absence of additional comparable specimens and measurements across similarly aged sites, it is difficult to hypothesize any broader affinities for AUH 35. However, the larger point is that there are indeed other cercopithecoid fossils in the late Miocene of East Africa that could represent the same taxon as AUH 35.

\section{INSERT FIGURE 13.6 APPROXIMATELY HERE, 1.5 COLUMN WIDTH}

Finally, it is important to point out that the species composition of the Baynunah fauna is most similar to that seen at contemporaneous sites in Northern, Central, and Eastern Africa, and is largely distinct from late Miocene faunas of Eurasia (Whybrow and Hill 1999; Hill et al. 2012; Bibi et al. 2013; Bibi et al. this volume). The guenon found at SHU 2-2 reinforces the view that the Baynunah fauna largely represents an extension of endemic African taxa into Arabia; however, there are some notable southern Asian elements in the fauna as well, such as the suid Propotamochoerus hysudricus and the bovid Pachyportax lati- 
dens, suggesting that some limited faunal mixing and possible exchange between Africa and Eurasia took place during the late Miocene of Arabia (Bishop and Hill 1999; Gentry 1999; Gilbert et al. 2014). Further support for this scenario comes from the bovid Prostrepsiceros aff. vinayaki and the rodents Myocricetodon and Abudhabia, which appear to be some of the few elements shared between the Baynunah fauna and those of Europe and western Asia (Bibi 2011; Kraatz et al. 2013; Kraatz this volume; Bibi et al. 2013; Bibi this volume; Gilbert et al. 2014). Thus, it is possible that the Arabian Peninsula acted as a filter during the late Miocene, with only some taxa - e.g. cercopithecoids, bovids, and rodents - able to disperse between Africa and Eurasia at this time.

\section{In Memoriam}

Before we could complete this contribution, my co-author, friend, colleague, and post-doctoral mentor Andrew Hill passed away. Andrew's efforts with his colleagues over the past 30 years in Abu Dhabi are directly responsible for the recovery of both primate specimens discussed here, and it was a typically amusing email from Abu Dhabi in January 2009 that first introduced me to AUH 1321 (as I recall, it was simply a picture of the specimen in Faysal's hand with the question "What is this?"). Andrew was a joy to be around, both in the lab and in the field; all those who knew him will miss him, and this chapter is dedicated to his memory.

\section{Acknowledgments}

We thank Faysal Bibi and the other editors for the invitation to contribute to this volume, and we thank Terry Harrison, Steve Frost, and the third anonymous reviewer of this manu- 
script for their helpful suggestions. Eric Delson, Steve Frost, John Fleagle, Peter Ungar, and Mike Plavcan provided assistance and advice with AUH 1321. We thank Eileen Westwig for access to primate specimens at the American Museum of Natural History; Darrin Lunde and Nicole Edmison for access to primate specimens at the Smithsonian National Museum of Natural History; Andrea Baden for help with Fig. 3; and B. Kraatz, E. Moacdieh, M. Al Neyadi, and staff from the Historic Environment Department at the Abu Dhabi Tourism and Culture Authority for their participation in fieldwork efforts. This research was supported by the Historic Environment Department of the Abu Dhabi Department of Culture and Tourism (formerly Abu Dhabi Tourism and Culture Authority, formerly Abu Dhabi Authority for Culture and Heritage); the Revealing Hominid Origins Initiative (National Science Foundation Grant BCS-0321893 to T. White and F.C. Howell); a National Science Foundation International Research Felloship (grant OISE-0852975 to F. Bibi); the Yale Peabody Museum; a Donnelley Fellowship from the Yale Institute for Biospheric Studies (to CCG); and a grant from the Yale University President's Office (to AH). 


\section{References}

Alba, D.M., Delson, E., Carnevale, G., Colombero, S., Dlfino, M., Giuntelli, P., Pavia, M., \& Pavia, G. (2014). First joint record of Mesopithecus and cf. Macaca in the Miocene of Europe. Journal of Human Evolution, 67, 1-18.

Alba, D.M., Montoya, P., Pina, M., Rook, L., Abella, J., Morales, J., \& Delson, E. (2015). First record of Mesopithecus (Cercopithecidae, Colobinae) from the Miocene of the Iberian Peninsula. Journal of Human Evolution, 88, 1-14.

Benefit, B.R., \& Pickford, M. (1986). Miocene fossil cercopithecoids from Kenya. American Journal of Physical Anthropology, 69, 441-464.

Benefit, B.R., McCrossin, M.L., Boaz, N.T., \& Pavlakis, P. (2008). New fossil cercopithecoids from the Late Miocene of As Sahabi, Libya. Garyounis Scientific Bulletin Special Issue, $5,265-282$.

Bibi, F. (2011). Mio-Pliocene Faunal Exchanges and African Biogeography: The Record of Fossil Bovids. PLoS ONE, 6, e16688. doi: 10.1371/journal.pone.0016688

Bibi, F. (this volume). Bovidae and Giraffidae from the Baynunah Formation. In F. Bibi, B. Kraatz, M. Beech, \& A. Hill (eds.) Sands of Time: Late Miocene Fossils from the Baynunah Formation, U.A.E. (pp. xxx). Cham: Springer.

Bibi, F., Shabel, A.B., Kraatz, B.P., \& Stidham, T. (2006). New fossil ratite (Aves: Palaeognathae) eggshell discoveries from the late Miocene Baynunah Formation of the United Arab Emirates, Arabian Peninsula. Palaeontologica Electronica, 9, 1-13.

Bibi, F., Hill, A., Beech, M., \& Yasin, W. (2013). Late Miocene fossils from the Baynunah Formation, United Arab Emirates: summary of a decade of new work. In: X. Wang, M. 
Fortelius, \& L.J. Flynn (Eds.), Neogene Terrestrial Mammalian Biostratigraphy and Chronology in Asia (pp. 583-594). New York: Columbia University Press.

Bibi, F., Kaya, F., Varela, S. (this volume). Paleoecology and Paleobiogeography of the Baynunah Fauna. In F. Bibi, B. Kraatz, M. Beech, \& A. Hill (eds.) Sands of Time: Late Miocene Fossils from the Baynunah Formation, U.A.E. (pp. xxx). Cham: Springer.

Bishop, L., Hill, A. (1999). Fossil Suidae from the Baynunah Formation, Emirate of Abu Dhabi, United Arab Emirates. In: P. J. Whybrow \& A. Hill (Eds.), Fossil Vertebrates of Arabia (pp. 254-270). New Haven and London: Yale University Press.

Bosworth, W., Huchon, P., \& McClay, K. (2005). The Red Sea and Gulf of Aden Basins. Journal of African Earth Sciences, 43, 334-378.

Clauzon, G., Suc, J-P., Gautier, F., Berger, A., \& Loutre, M-F. (1996). Alternate interpretation of the Messinian salinity crisis: Controversy resolved? Geology, 24, 363-366.

Delson, E. (1975). Evolutionary History of the Cercopithecidae. In: F. Szalay (Ed.), Approaches to Primate Paleobiology. Volume 5: Contributions to Primatology (pp. 167-217). Basel: Karger.

Delson, E. (1980). Fossil macaques, phyletic relationships and a scenario of deployment. In: D.G. Lindburg (Ed.), The Macaques: Studies in Ecology, Behavior and Evolution (pp. 10-30). New York: Van Nostrand.

Delson, E. (1994). Evolutionary history of the colobine monkeys in paleoenvironmental perspective. In: A.G. Davies \& J.H. Oates (Eds.), Colobine Monkeys: Their Ecology, Behaviour, and Evolution (pp. 11-43). Cambridge: Cambridge University Press. 
Delson, E. (1996). The oldest monkeys in Asia. In: O. Takenaka (Ed.), Abstracts, International Symposium: Evolution of Asian Primates (pp. 40). Primate Research Institute, Inuyama: Japan.

Delson, E., Terranova, C.J., Jungers, W.L., Sargis, E.J., Jablonski, N.G., \& Dechow, P.C. (2000). Body mass in Cercopithecidae (Primates, Mammalia): estimation and scaling in extinct and extant taxa. Anthropological Papers of the American Museum of Natural History, 8, 1-159.

Friend, P.F. (1999). Rivers of the Lower Baynunah Formation, Emirate of Abu Dhabi, United Arab Emirates. In: P. J. Whybrow \& A. Hill (Eds.), Fossil Vertebrates of Arabia (pp. 39-49). New Haven and London: Yale University Press.

Frost, S.R., Haile-Selassie, Y., \& Hlusko, L. (2009). Cercopithecidae. In: Y. Haile-Selassie \& G. Woldegabriel (Eds.), Ardipithecus kadabba: late Miocene evidence from the Middle Awash, Ethiopia (pp. 135-158). Berkeley, University of California Press.

Gautier, F., Clauzon, G., Suc, J-P., Cravatte, J., \& Violenti, D. (1994). Age et durée de la crise de salinité messinienne. Comptes Rendus de l'Academie des Sciences II A, 318, 11031109.

Gentry, A.W. (1999). Fossil pecorans from the Baynunah Formation, Emirate of Abu Dhabi, United Arab Emirates. In P.J. Whybrow \& A. Hill (Eds.), Fossil vertebrates of Arabia. With emphasis on the late Miocene faunas, geology, and palaeoenvironments of the Emirate of Abu Dhabi, United Arab Emirates (pp. 290-316). New Haven: Yale University Press.

Geraads, D. (1987). Dating the northern African cercopithecid fossil record. Human Evolution, 2, 19-27. 
Gibert, L., Scott, G.R., Montoya, P., Ruiz-Sanchez, F.J., Morales, J., Luque, L., Abella, J., \& Leria, M. (2013). Evidence for an Africa-Iberian mammal dispersal during the pre-evaporitic Messinian. Geology, 41, 691-694.

Gilbert, C.C., Goble, E.D., Hill, A. (2010). Miocene Cercopithecoidea from the Tugen Hills, Kenya. Journal of Human Evolution, 59, 465-483.

Gilbert, C.C., Bibi, F., Hill, A., \& Beech, M.J. (2014). Early guenon from the late Miocene Baynunah Formation, Abu Dhabi, with implications for cercopithecoids biogeography and evolution. Proceedings of the National Academy of Sciences, USA, 111, 1011910124.

Harrison, T., \& Delson, E. (2007). ?Mesopithecus sivalensis from the Late Miocene of the Siwaliks. American Journal of Physical Anthropology, 44S, 126.

Hill, A. (1999). Late Miocene sub-Saharan vertebrates, and their relation to the Baynunah fauna, Abu Dhabi, United Arab Emirates. In: P. J. Whybrow \& A. Hill (Eds.), Fossil Vertebrates of Arabia (pp. 420-429). New Haven and London: Yale University Press.

Hill, A., \& Gundling, T. (1999). A monkey (Primates; Cercopithecidae) from the Late Miocene of Abu Dhabi, United Arab Emirates. In: P. J. Whybrow \& A. Hill (Eds.), Fossil Vertebrates of Arabia (pp. 198-202). New Haven and London: Yale University Press.

Hill, A., Bibi, F., Beech, M., \& Yasin al-Tikriti, W. (2012). Before archaeology: life and environments in the Miocene of Abu Dhabi. In: D. Potts \& P. Hellyer (Eds.), Fifty Years after Umm al-Nar - Second International Conference on the Archaeology of the United Arab Emirates (pp. 20-33). Ministry of Culture, Youth and Community Development, Abu Dhabi: UAE. 
Hlusko, L.J. (2007). A new late Miocene species of Paracolobus and other Cercopithecoidea (Mammalia: Primates) fossils from Lemudong'o, Kenya. Kirtlandia, 56, 72-85.

Hooijer, D.A. (1963). Miocene Mammalia of the Congo. Annales Musee Royal de l'Afrique Central, 8th ser., 46, 1-71.

Ji, X., Jablonski, N.G., Su, D.F., Deng, C., Flynn, L.J., You, Y., \& Kelley, J. (2013). Juvenile hominoid cranium from the terminal Miocene of Yunnan, China. Chinese Science Bulletin, $58,3771-3779$.

Köhler, M., Moyà-Solà, S., \& Alba, D.M. (2000). Macaca (Primates, Cercopithecidae) from the late Miocene of Spain. Journal of Human Evolution, 38, 447-452.

Koufos, G.D. (2013). Neogene Mammal Biostratigraphy and Chronology of Greece. In: X. Wang, L.J. Flynn, \& M. Fortelius (Eds.), Fossil Mammals of Asia: Neogene Terrestrial Mammalian Biostratigraphy and Chronology (pp. 595-621). New York: Columbia University Press.

Kraatz, B. (this volume). Rodents from the Baynunah Formation. In F. Bibi, B. Kraatz, M. Beech, \& A. Hill (eds.) Sands of Time: Late Miocene Fossils from the Baynunah Formation, U.A.E. (pp. xxx). Cham: Springer.

Kraatz, B., Bibi, F., Hill, A., \& Beech, M. (2013). A New Fossil Thryonomyid (Rodentia: Thryonomyidae) from the Late Miocene of the United Arab Emirates and the origin of African Cane Rats. Naturwissenschaften, 100, 437-449.

Krijgsman, W., Hilgen, F.J., Raffi, I., Sierro, F.J., \& Wilsonk, D.S. (1999). Chronology, causes and progression of the Messinian salinity crisis. Nature, 400, 652-655. 
Leakey, M.G., Teaford, M.F., \& Ward, C.V., (2003). Cercopithecidae from Lothagam. In: M.G. Leakey \& J.M. Harris (Eds.), Lothagam: The Dawn of Humanity in Eastern Africa (pp. 201-248). New York: Columbia University Press.

Lourens, L.J., Hilgen, F.J., Laskar, J., Shackleton, N.J., \& Wilson, D.S. (2004). The Neogene Period. In: F. Gradstein, J. Ogg, \& A. Smith (Eds.), A Geologic Timescale 2004 (pp. 409440). Cambridge: Cambridge University Press.

McDougall, I., \& Feibel, C.S. (2003). Numerical age control for the Miocene-Pliocene succession at Lothagam, a hominoid-bearing sequence in the northern Kenya Rift. In: M.G. Leakey \& J.M. Harris (Eds.), Lothagam: The Dawn of Humanity in Eastern Africa (pp. 43-64). New York: Columbia University Press.

McKenzie, J.A. (1999). From desert to deluge in the Mediterranean. Nature, 400, 613-614.

Nakatsukasa, M., Mbua, E., Sawada, Y., Sakai, T., Nakaya, H., Yano, W., \& Kunimatsu, Y. (2010). Earliest colobine skeletons from Nakali, Kenya. American Journal of Physical Anthropology, 143, 365-382.

Peppe, D. J., Evans, D. A. D., Beech, M., Hill, A., Bibi, F. (this volume). Magnetostratigraphy of the Baynunah Formation. In F. Bibi, B. Kraatz, M. Beech, \& A. Hill (eds.) Sands of Time: Late Miocene Fossils from the Baynunah Formation, U.A.E. (pp. xxx). Cham: Springer.

Plavcan, J.M., Ward, C.V., \& Manthi, F.K. (2013). Diminutive cercopithecine teeth from Kanapoi, Kenya, and implications for the evolution of body size and diversity in guenons. American Journal of Physical Anthropology, S56, 222.

Rossie, J.B., Gilbert, C.C., \& Hill, A. (2013). Early cercopithecid monkeys from the Tugen Hills, Kenya. Proceedings of the National Academy of Sciences, USA, 110, 5818-5822. 
Rouchy, J-M., \& Caruso, A. (2006). The Messinian salinity crisis in the Mediterranean basin: A reassessment of the data and an integrated scenario. Sedimentary Geology, 188$189,35-67$.

Senut, B. (1994). Cercopithecoidea Néogenes et Quaternaires du Rift Occidental (Ouganda). In: B. Senut \& M. Pickford (Eds.), Geology and Palaeobiology of the Albertine Rift Valley, Uganda-Zaire, vol. II: Palaeobiology (pp. 195-205). Orleans: CIFEG Occasional Publication (1994/29).

Sierro, F.J., Flores, J.A., Zamarreno, I., Vazquez, A., Utrilla, R., Frances, G., Hilgen, F.J., \& Krijgsman, W. (1999). Messinian pre-evaporite sapropels and precession induced oscillations in western Mediterranean climate. Marine Geology, 153, 137-146.

Simpson, S.W., Kleinsasser L., Quade, J., Levin, N.E., McIntosh, W.C., Dunbar, N., Semaw, S., \& Rogers, M.J. (2015). Late Miocene hominin teeth from the Gona Paleoanthropological Researh Project area, Afar Ethiopia. Journal of Human Evolution 81: 68-82.

Suwa, G., Beyene, Y., Nakaya, H., Bernor, R.L., Boisserie, J-R., Bibi, F., Ambrose, S.H., Sano, K., Katoh, S., \& Asfaw, B. (2015). Newly discovered cercopithecid, equid, and other mammalian fossils from the Chorora Formation, Ethiopia. Anthropological Science, 123, 19-39.

Van Couvering, J.A., Castradori, D., Cita, M.B., Hilgen, F.J., \& Rio, D. (2000). The base of the Zanclean Stage and of the Pliocene Series. Episodes, 23, 179-187.

Whybrow, P.J., \& Hill, A. (Eds.). (1999). Fossil Vertebrates of Arabia: with Emphasis on the Late Miocene Faunas, Geology, and Palaeoenvironments of the Emirate of Abu Dhabi, United Arab Emirates. New Haven and London: Yale University Press. 


\section{Figure Captions}

Figure 13.1. Map illustrating the location of the two monkey-bearing fossil localities in the Baynunah Formation; AUH 35 is from JDH 3 and AUH 1321 is from SHU 2-2. Top right inset shows the location of the SHU 2-2 excavation (kite aerial photography by Nathan Craig). Modified from Gilbert et al. (2014).

Figure 13.2. a) AUH 35, male lower left canine of an unknown cercopithecid; b) AUH 1321, lower left molar (likely $\mathrm{M}_{1}$ ) of Cercopithecini sp. indet.

Figure 13.3. Comparison of cercopithecine $\mathrm{dP}_{4}$ and $\mathrm{M}_{1}$ crown and root morphology. Top row: Distal views of cercopithecine teeth compared to AUH 1321, scaled to approximately the same buccolingual width. From left, Chlorocebus aethiops lower left $\mathrm{dP}_{4}$, Macaca fascicularis lower left $\mathrm{dP}_{4}$, Cercopithecus mitis lower left $\mathrm{dP}_{4}, \mathrm{AUH} 1321$, and Allochrocebus lhoesti lower left $\mathrm{M}_{1}$. Horizontal arrows highlight clear enamel "bulging" at the base of the crown on the buccal and lingual sides of the $\mathrm{dP}_{4} \mathrm{~s}$. Typical guenon $\mathrm{M}_{1} \mathrm{~s}$, on the other hand, do not exhibit a high degree of flare and are straight-sided at the base of the crown, with robust proximal roots that do not display any obvious constriction. Diagonal arrows highlight lingual root resorption typical of $\mathrm{dP}_{4} \mathrm{~S}$ compared to the lack of any lingual root resorption seen in AUH 1321. Bottom row: Buccal views of guenon permanent lower left molars compared to AUH 1321, scaled to approximately the same mesiodistal length. From left, Cercopithecus cephus $\mathrm{M}_{1}$, AUH 1321, and Cercopithecus ascanius $\mathrm{M}_{2}$. Note that similar degrees of distal root flare as observed in AUH 1321 can also be found in this small sample of extant guenons. Also note that the distal end of AUH 1321 appears to be slightly broken, making it highly likely that the distal root would have been even longer, more typical of permanent molars rather than $\mathrm{dP}_{4} \mathrm{~s}$. Modified from Gilbert et al. (2014); see text for further details. 
Figure 13.4. Results of discriminant function analyses (DFA) on a sample of cercopithecine $\mathrm{dP}_{4} \mathrm{~S}$ and $\mathrm{M}_{1} \mathrm{~S}$ using five crown and root shape variables: a) DFA of cercopithecine teeth, correctly classifying $94.6 \%$ (88\% cross-validated) of specimens as either $\mathrm{M}_{1} \mathrm{~s}$ or $\mathrm{dP}_{4} \mathrm{~s}$. Note that AUH 1321 plots well within the $\mathrm{M}_{1}$ range (and outside the $\mathrm{dP}_{4}$ range) on discriminant function 1 and is classified as an $\mathrm{M}_{1}$ with a posterior probability of $99.2 \%$; b) DFA of cercopithecine and Macaca teeth, correctly classifying 79.3\% (73.9\% cross-validated) of specimens as guenon $M_{1} s$, guenon $d_{4} s$, macaque $M_{1} s$, or macaque $d_{4} s$. AUH 1321 plots well within the range of guenon $\mathrm{M}_{1} \mathrm{~s}$ (blue minimum convex polygon), outside the range of macaque $\mathrm{M}_{1} \mathrm{~s}$ (purple minimum convex polygon), and well outside the range of guenon $\mathrm{dP}_{4} \mathrm{~S}$ and macaque $\mathrm{dP}_{4} \mathrm{~s}$. AUH 1321 is classified as a guenon $\mathrm{M}_{1}$ with a posterior probability of 97.5\%. Modified from Gilbert et al. (2014).

Figure 13.5. Results of discriminant functions analyses (DFA) based on seven variables of lower canine size and shape. Note that AUH 35 falls in the area of overlap between cercopithecine and colobine specimens when compared to a) extant and fossil male specimens combined; and b) extant male specimens alone. See text for further details. For raw measurements, see Appendix.

Figure 13.6. Hypothesized cercopithecoid dispersal routes out of Africa in relation to the known late Miocene fossil record. The oldest recognized colobines, an indeterminate species and Microcolobus tugenensis, are both found at sites in the Tugen Hills, Kenya at $\sim 12.5$ and $\sim 8.8-9.5 \mathrm{Ma}$, respectively (light green circle, Benefit and Pickford, 1986; Rossie et al., 2013); Microcolobus is also found at Nakali $~ 9.5 \mathrm{Ma}$ (light green circle, Nakatsukasa et al., 2010). Kenyan late Miocene cercopithecoids also include Paracolobus enkorikae from 
Lemudong’o ( 6 Ma, light green circle, Hlusko, 2007), two unnamed colobines (light green circle) as well as Parapapio lothagamensis (light blue circle) known from 7.4-5.5 Ma in the Turkana Basin (Leakey et al., 2003; McDougall et al., 2003), and two specimens attributed to cf. Pp. lothagamensis in the Tugen Hills, Kenya, as well ( 6.1-5.7 Ma, light blue circle, Gilbert et al., 2010). Other late Miocene African cercopithecoids include the oldest cercopithecine and early colobine specimens representing indeterminate species from the Chorora Formation, Ethiopia ( 8.0 Ma, purple circle, Suwa et al., 2015), and cf. Kuseracolobus aramisi (light green circle), cf. Pliopapio alemui (light blue circle), and indeterminate colobine and cercopithecine specimens (purple circle) from the late Miocene Adu-Asa and Kuseralee Formations, Ethiopia ( 6.3-5.2 Ma, Frost et al., 2009; Simpson et al., 2015). An indeterminate papionin is documented from the late Miocene of Ongoliba, Congo (purple circle, Hooijer, 1963; Delson, 1980), and colobine teeth assigned to cf. Paracolobus sp. derive from the late Miocene Nkondo Formation, Uganda (light green circle, Senut, 1994). Macaca spp. (dark blue circles) are located throughout N. Africa at sites ranging in age from $\sim 6.5$ to $5.5 \mathrm{Ma}$ (Delson, 1980; Kohler et al., 2000; Geraads, 1987; Benefit et al., 2008), and Macaca spp. first appear in Europe 6.0-5.3 Ma and in China during the early Pliocene (Delson, 1980, 1996; Delson et al., 2000; Kohler et al., 2000; Alba et al., 2014). The oldest colobine outside of Africa, Mesopithecus (green circles), is known from a number of late Miocene sites securely dated between 8.5-5.3 Ma in Greece, Macedonia, Italy, Spain, Ukraine, Iran, Afghanistan, possibly Pakistan, and China (Delson, 1994; Ji et al., 2013; Koufos, 2013; Alba et al., 2015). Three dispersal routes for cercopithecoids can be hypothesized: Route 1 imagines a dispersal event over the Straits of Gibraltar or Mediterranean Basin into Europe and Asia, Route 2 postulates a dispersal event through the Arabian Sinai Peninsula, and Route 3 suggests a migration over the Arabian Straits of Bab el Mandeb. The discovery of AUH 1321 and AUH 35 in Abu Dhabi at 8-6 Ma (red circle), contemporaneous with the first appearance of cercop- 
ithecines in Africa and Mesopithecus sp. in Eurasia, and 1-2 million years earlier than the appearance of Macaca spp. in Eurasia, suggests scenarios 2 and 3 were more likely prior to scenario 1 . None of these scenarios is mutually exclusive and may have occurred in combination or succession. Modified from Gilbert et al. (2014).

Table 13.1. Comparison of shape characteristics between cercopithecine $\mathrm{dP}_{4} \mathrm{~s}$ and $\mathrm{M}_{1} \mathrm{~s}$.

\begin{tabular}{|c|c|c|c|}
\hline Character & $\mathbf{d P}_{4}$ & $\mathbf{M}_{1}$ & AUH 1321 \\
\hline Crown elongation $(\mathrm{MD}>\mathrm{BL})$ & Great & Slight-Moderate & Moderate \\
\hline Basal Crown Flare & High & Moderate to High & Moderate \\
\hline $\begin{array}{l}\text { Constriction at the cervix or crown/root } \\
\text { junction }\end{array}$ & Great & Slight to moderate & Slight \\
\hline Root Length & Short-Moderate & Moderate-Long & $\begin{array}{l}\text { Moderate- } \\
\text { Long? }\end{array}$ \\
\hline Distal Root Orientation & Distally splayed & $\begin{array}{l}\text { Straight-Distally } \\
\text { splayed }\end{array}$ & $\begin{array}{l}\text { Distally } \\
\text { splayed }\end{array}$ \\
\hline Root Asymmetry with moderate wear & $\begin{array}{l}\text { Resorption on lingual } \\
\text { side }\end{array}$ & None & None \\
\hline
\end{tabular}




\section{Appendix}

Extant and fossil male cercopithecoid lower canine measurements used in this study. See main text for details.

\begin{tabular}{|c|c|c|c|c|}
\hline Subfamily & Species & Canine height & Canine length & Canine width \\
\hline Cercopithecinae & $\begin{array}{c}\text { Cercocebus torqua- } \\
\text { tus }\end{array}$ & 20.0 & 5.8 & 9.0 \\
\hline Cercopithecinae & $\begin{array}{c}\text { Cercocebus torqua- } \\
\text { tus }\end{array}$ & 18.8 & 5.6 & 9.5 \\
\hline Cercopithecinae & Cercocebus atys & 10.7 & 5.6 & 8.8 \\
\hline Cercopithecinae & $\begin{array}{l}\text { Lophocebus albi- } \\
\text { gena }\end{array}$ & 15.7 & 5.1 & 8.4 \\
\hline Cercopithecinae & $\begin{array}{c}\text { Allenopithecus ni- } \\
\text { groviridis }\end{array}$ & 12.9 & 3.3 & 7.4 \\
\hline Cercopithecinae & $\begin{array}{l}\text { Miopithecus } \\
\text { ogouensis }\end{array}$ & 7.9 & 2.3 & 4.1 \\
\hline Cercopithecinae & $\begin{array}{l}\text { Miopithecus } \\
\text { ogouensis }\end{array}$ & 7.4 & 2.1 & 4.0 \\
\hline Cercopithecinae & $\begin{array}{l}\text { Miopithecus } \\
\text { ogouensis }\end{array}$ & 7.3 & 1.8 & 3.6 \\
\hline Cercopithecinae & $\begin{array}{l}\text { Chlorocebus } \\
\text { pygerythrus }\end{array}$ & 13.5 & 4.0 & 6.8 \\
\hline Cercopithecinae & Chlorocebus & 9.0 & 2.8 & 5.2 \\
\hline
\end{tabular}




\begin{tabular}{|c|c|c|c|c|}
\hline Cercopithecinae & $\begin{array}{l}\text { Chlorocebus } \\
\text { pygerythrus }\end{array}$ & 14.7 & 3.4 & 6.1 \\
\hline Cercopithecinae & $\begin{array}{l}\text { Chlorocebus } \\
\text { pygerythrus }\end{array}$ & 12.0 & 3.5 & 5.9 \\
\hline Cercopithecinae & $\begin{array}{l}\text { Chlorocebus } \\
\text { pygerythrus }\end{array}$ & 15.1 & 4.3 & 6.0 \\
\hline Cercopithecinae & $\begin{array}{l}\text { Chlorocebus } \\
\text { pygerythrus }\end{array}$ & 13.1 & 4.0 & 7.0 \\
\hline Cercopithecinae & $\begin{array}{c}\text { Chlorocebus cyno- } \\
\text { suros }\end{array}$ & 15.3 & 3.7 & 6.1 \\
\hline Cercopithecinae & Erythrocebus patas & 17.1 & 5.2 & 9.5 \\
\hline Cercopithecinae & Erythrocebus patas & 19.0 & 4.5 & 9.4 \\
\hline Cercopithecinae & Erythrocebus patas & 19.8 & 5.0 & 9.5 \\
\hline Cercopithecinae & $\begin{array}{c}\text { Allochrocebus } \\
\text { Ihoesti }\end{array}$ & 15.3 & 3.8 & 6.1 \\
\hline Cercopithecinae & $\begin{array}{l}\text { Allochrocebus } \\
\text { Ihoesti }\end{array}$ & 13.7 & 4.2 & 6.7 \\
\hline Cercopithecinae & $\begin{array}{l}\text { Allochrocebus } \\
\text { Ihoesti }\end{array}$ & 13.4 & 5.5 & 7.3 \\
\hline Cercopithecinae & Cercopithecus mitis & 14.9 & 3.8 & 8.1 \\
\hline Cercopithecinae & $\begin{array}{c}\text { Cercopithecus asca- } \\
\text { nius }\end{array}$ & 11.2 & 2.7 & 4.4 \\
\hline
\end{tabular}




\begin{tabular}{|c|c|c|c|c|}
\hline Cercopithecinae & $\begin{array}{c}\text { Cercopithecus asca- } \\
\text { nius }\end{array}$ & 11.8 & 3.2 & 5.6 \\
\hline Cercopithecinae & $\begin{array}{c}\text { Cercopithecus asca- } \\
\text { nius }\end{array}$ & 11.1 & 2.8 & 5.0 \\
\hline Cercopithecinae & $\begin{array}{c}\text { Cercopithecus asca- } \\
\text { nius }\end{array}$ & 9.8 & 3.1 & 5.2 \\
\hline Cercopithecinae & $\begin{array}{c}\text { Cercopithecus asca- } \\
\text { nius }\end{array}$ & 10.6 & 3.3 & 5.1 \\
\hline Cercopithecinae & $\begin{array}{c}\text { Cercopithecus asca- } \\
\text { nius }\end{array}$ & 11.9 & 3.3 & 5.2 \\
\hline Cercopithecinae & $\begin{array}{c}\text { Cercopithecus asca- } \\
\text { nius }\end{array}$ & 10.8 & 3.0 & 4.6 \\
\hline Cercopithecinae & $\begin{array}{c}\text { Cercopithecus } \\
\text { pogonias }\end{array}$ & 10.9 & 3.6 & 5.4 \\
\hline Cercopithecinae & $\begin{array}{c}\text { Cercopithecus } \\
\text { pogonias }\end{array}$ & 10.9 & 2.9 & 4.6 \\
\hline Cercopithecinae & $\begin{array}{c}\text { Cercopithecus } \\
\text { pogonias }\end{array}$ & 12.1 & 3.4 & 5.3 \\
\hline Cercopithecinae & $\begin{array}{c}\text { Cercopithecus } \\
\text { pogonias }\end{array}$ & 14.6 & 3.6 & 5.3 \\
\hline Cercopithecinae & $\begin{array}{c}\text { Cercopithecus } \\
\text { pogonias }\end{array}$ & 12.4 & 3.6 & 5.6 \\
\hline Cercopithecinae & $\begin{array}{c}\text { Cercopithecus } \\
\text { pogonias }\end{array}$ & 11.9 & 3.5 & 4.9 \\
\hline Cercopithecinae & Cercopithecus & 14.2 & 3.2 & 6.3 \\
\hline
\end{tabular}


pogonias

\begin{tabular}{|c|c|c|c|c|}
\hline Cercopithecinae & Macaca sylvanus & 14.5 & 4.9 & 8.9 \\
\hline Cercopithecinae & Macaca sylvanus & 18.4 & 5.6 & 9.7 \\
\hline Cercopithecinae & Macaca sylvanus & 17.7 & 5.1 & 8.3 \\
\hline Cercopithecinae & Macaca sylvanus & 17.3 & 5.3 & 8.9 \\
\hline Cercopithecinae & Macaca sylvanus & 16.7 & 5.4 & 9.9 \\
\hline Cercopithecinae & Macaca majori & 13.7 & 5.0 & 7.0 \\
\hline Cercopithecinae & Macaca majori & 15.2 & 4.8 & 7.1 \\
\hline Cercopithecinae & Macaca majori & 12.3 & 5.0 & 7.0 \\
\hline Cercopithecinae & Macaca majori & 10.0 & 4.8 & 6.6 \\
\hline Cercopithecinae & Macaca majori & 11.1 & 5.3 & 6.4 \\
\hline Cercopithecinae & Macaca ?pliocena & 15.1 & 5.0 & 9.6 \\
\hline Cercopithecinae & Macaca ?florentina & 14.5 & 6.0 & 10.7 \\
\hline Cercopithecinae & Macaca ?florentina & 18.4 & 6.0 & 11.6 \\
\hline Cercopithecinae & Macaca ?florentina & 17.0 & 5.4 & 9.5 \\
\hline Cercopithecinae & Macaca ?florentina & 20.4 & 6.1 & 11.0 \\
\hline Cercopithecinae & Macaca ?florentina & 18.0 & 6.0 & 10.3 \\
\hline Cercopithecinae & Macaca ?prisca & 16.5 & 5.8 & 8.2 \\
\hline Cercopithecinae & Paradolichopithecus & 21.1 & 7.6 & 12.1 \\
\hline
\end{tabular}


arvernensis

\begin{tabular}{|c|c|c|c|c|}
\hline Cercopithecinae & $\begin{array}{c}\text { Paradolichopithecus } \\
\text { sushkini }\end{array}$ & 23.0 & 8.5 & 15.0 \\
\hline Cercopithecinae & $\begin{array}{l}\text { ?Procynocephalus } \\
\text { gansuensis }\end{array}$ & 21.7 & 8.7 & 12.9 \\
\hline Cercopithecinae & Macaca thibetana & 20.6 & 6.1 & 11.1 \\
\hline Cercopithecinae & Macaca thibetana & 19.3 & 6.7 & 10.6 \\
\hline Cercopithecinae & Macaca thibetana & 13.8 & 6.2 & 10.1 \\
\hline Cercopithecinae & Macaca nigra & 18.7 & 6.3 & 10.2 \\
\hline Cercopithecinae & Macaca nemestrina & 22.4 & 6.7 & 10.7 \\
\hline Cercopithecinae & Macaca tonkeana & 15.0 & 7.8 & 8.7 \\
\hline Cercopithecinae & Macaca tonkeana & 13.8 & 8.7 & 9.0 \\
\hline Cercopithecinae & Macaca arctoides & 12.5 & 5.2 & 8.8 \\
\hline Cercopithecinae & Macaca fuscata & 14.0 & 5.6 & 7.9 \\
\hline Cercopithecinae & Macaca sp. & 9.0 & 6.7 & 9.5 \\
\hline Cercopithecinae & Papio hamadryas & 23.3 & 8.3 & 13.4 \\
\hline Cercopithecinae & Papio hamadryas & 20.5 & 8.4 & 13.3 \\
\hline Cercopithecinae & Papio kindae & 18.8 & 5.2 & 8.6 \\
\hline Cercopithecinae & Papio kindae & 17.7 & 5.0 & 7.8 \\
\hline Cercopithecinae & Papio kindae & 14.4 & 5.1 & 8.2 \\
\hline
\end{tabular}




\begin{tabular}{|c|c|c|c|c|}
\hline Cercopithecinae & Papio kindae & 16.3 & 5.6 & 9.2 \\
\hline Cercopithecinae & Papio kindae & 14.1 & 4.3 & 5.7 \\
\hline Cercopithecinae & Papio kindae & 16.2 & 5.2 & 7.6 \\
\hline Cercopithecinae & Papio kindae & 16.9 & 5.0 & 8.3 \\
\hline Cercopithecinae & Papio kindae & 16.7 & 4.6 & 7.2 \\
\hline Cercopithecinae & Papio papio & 22.5 & 7.9 & 13.6 \\
\hline Cercopithecinae & Papio cynocephalus & 19.9 & 7.9 & 11.9 \\
\hline Cercopithecinae & Papio anubis & 24.3 & 7.6 & 13.3 \\
\hline Cercopithecinae & Papio anubis & 13.3 & 8.1 & 13.7 \\
\hline Cercopithecinae & Papio anubis & 21.9 & 8.4 & 15.4 \\
\hline Cercopithecinae & Mandrillus sphinx & 30.4 & 10.8 & 15.9 \\
\hline Cercopithecinae & Mandrillus sphinx & 30.2 & 8.7 & 16.0 \\
\hline Cercopithecinae & Mandrillus sphinx & 34.8 & 16.9 & 20.2 \\
\hline Cercopithecinae & Mandrillus sphinx & 23.0 & 10.6 & 14.2 \\
\hline Cercopithecinae & Mandrillus sphinx & 28.4 & 12.4 & 13.5 \\
\hline Cercopithecinae & Mandrillus sphinx & 29.4 & 9.7 & 13.5 \\
\hline Cercopithecinae & Mandrillus sphinx & 30.8 & 8.8 & 12.2 \\
\hline Cercopithecinae & Mandrillus sphinx & 24.3 & 8.6 & \\
\hline
\end{tabular}




\begin{tabular}{|c|c|c|c|c|}
\hline Cercopithecinae & Mandrillus sphinx & 25.6 & 9.5 & 17.0 \\
\hline Cercopithecinae & $\begin{array}{c}\text { Mandrillus leu- } \\
\text { cophaeus }\end{array}$ & 25.2 & 9.8 & 12.4 \\
\hline Cercopithecinae & $\begin{array}{c}\text { Mandrillus leu- } \\
\text { cophaeus }\end{array}$ & 21.0 & 8.2 & 11.0 \\
\hline Cercopithecinae & $\begin{array}{c}\text { Mandrillus leu- } \\
\text { cophaeus }\end{array}$ & 28.7 & 8.2 & 13.6 \\
\hline Cercopithecinae & $\begin{array}{c}\text { Mandrillus leu- } \\
\text { cophaeus }\end{array}$ & 27.1 & 8.3 & 14.6 \\
\hline Cercopithecinae & $\begin{array}{c}\text { Mandrillus leu- } \\
\text { cophaeus }\end{array}$ & 31.1 & 8.2 & 13.7 \\
\hline Cercopithecinae & $\begin{array}{c}\text { Mandrillus leu- } \\
\text { cophaeus }\end{array}$ & 27.3 & 7.1 & 12.3 \\
\hline Cercopithecinae & Papio angusticeps & 26.5 & 6.1 & 11.5 \\
\hline Cercopithecinae & Papio angusticeps & 22.0 & 6.3 & 10.9 \\
\hline Cercopithecinae & Papio robinsoni & 19.2 & 7.0 & 11.6 \\
\hline Cercopithecinae & Papio robinsoni & 24.5 & 7.0 & 12.1 \\
\hline Cercopithecinae & Papio robinsoni & 21.6 & 8.3 & 12.0 \\
\hline Cercopithecinae & Papio robinsoni & 24.3 & 9.0 & 15.4 \\
\hline Cercopithecinae & Papio robinsoni & 30.2 & 8.6 & 15.0 \\
\hline Cercopithecinae & Papio robinsoni & 26.6 & 8.1 & 13.7 \\
\hline
\end{tabular}




\begin{tabular}{|c|c|c|c|c|}
\hline Cercopithecinae & Papio robinsoni & 30.7 & 7.4 & 14.2 \\
\hline Cercopithecinae & Papio ursinus & 21.7 & 7.4 & 12.8 \\
\hline Cercopithecinae & Papio ursinus & 28.4 & 8.1 & 13.9 \\
\hline Cercopithecinae & Papio ursinus & 6.7 & 8.2 & 13.8 \\
\hline Cercopithecinae & Papio ursinus & 28.0 & 6.6 & 12.6 \\
\hline Cercopithecinae & Papio ursinus & 32.6 & 7.7 & 14.5 \\
\hline Cercopithecinae & Papio ursinus & 28.6 & 7.4 & 12.7 \\
\hline Cercopithecinae & Papio ursinus & 33.9 & 7.6 & 14.6 \\
\hline Cercopithecinae & Papio ursinus & 27.9 & 7.7 & 15.2 \\
\hline Cercopithecinae & Papio ursinus & 31.3 & 7.8 & 14.4 \\
\hline Cercopithecinae & Papio ursinus & 30.0 & 9.2 & 15.7 \\
\hline Cercopithecinae & Papio ursinus & 20.5 & 7.8 & 14.2 \\
\hline Cercopithecinae & Papio ursinus & 32.9 & 8.5 & 16.1 \\
\hline Cercopithecinae & Papio ursinus & 29.2 & 8.2 & 15.4 \\
\hline Cercopithecinae & Papio ursinus & 36.3 & 7.9 & 14.3 \\
\hline Cercopithecinae & Papio ursinus & 31.1 & 7.7 & 13.6 \\
\hline Cercopithecinae & Papio ursinus & 29.3 & 7.5 & 13.4 \\
\hline Cercopithecinae & Papio ursinus & 32.9 & 8.1 & 14 \\
\hline
\end{tabular}




\begin{tabular}{|c|c|c|c|c|}
\hline Cercopithecinae & Papio ursinus & 30.3 & 7.9 & 13.7 \\
\hline Cercopithecinae & Papio ursinus & 29.3 & 10.6 & 13.2 \\
\hline Cercopithecinae & Papio ursinus & 33.0 & 7.8 & 13.6 \\
\hline Cercopithecinae & Papio ursinus & 29.7 & 8.6 & 15.1 \\
\hline Cercopithecinae & Papio ursinus & 33.9 & 7.6 & 14.7 \\
\hline Cercopithecinae & Papio ursinus & 28.2 & 7.4 & 13.2 \\
\hline Cercopithecinae & Papio ursinus & 32.5 & 8.2 & 15.2 \\
\hline Cercopithecinae & Papio ursinus & 32.2 & 7.2 & 14.7 \\
\hline Cercopithecinae & Papio ursinus & 31.1 & 7.1 & 13.8 \\
\hline Cercopithecinae & Papio ursinus & 32.2 & 7.4 & 14.3 \\
\hline Cercopithecinae & Papio ursinus & 33.7 & 7.8 & 14.4 \\
\hline Cercopithecinae & Papio ursinus & 31.7 & 8.1 & 14.5 \\
\hline Cercopithecinae & Papio ursinus & 29.1 & 7.7 & 13.9 \\
\hline Cercopithecinae & Papio ursinus & 31.5 & 7.6 & 13.6 \\
\hline Cercopithecinae & Papio ursinus & 33.1 & 8.3 & 16.2 \\
\hline Cercopithecinae & Papio ursinus & 31.7 & 7.5 & 13.0 \\
\hline Cercopithecinae & Papio ursinus & 34.9 & 8.7 & 15.1 \\
\hline Cercopithecinae & Papio ursinus & 26.8 & 7.8 & 13 \\
\hline
\end{tabular}




\begin{tabular}{|c|c|c|c|c|}
\hline Cercopithecinae & Papio ursinus & 33.1 & 7.6 & 12.9 \\
\hline Cercopithecinae & Papio ursinus & 33.2 & 8.7 & 16.6 \\
\hline Cercopithecinae & Papio ursinus & 28.2 & 7.8 & 13.4 \\
\hline Cercopithecinae & Papio ursinus & 32.6 & 8.0 & 14.5 \\
\hline Cercopithecinae & Papio ursinus & 22.8 & 7.4 & 13.4 \\
\hline Cercopithecinae & Papio ursinus & 31.8 & 7.8 & 14.7 \\
\hline Cercopithecinae & Papio ursinus & 32.4 & 7.4 & 12.9 \\
\hline Cercopithecinae & Papio ursinus & 29.7 & 8.5 & 13.7 \\
\hline Cercopithecinae & Papio ursinus & 27.8 & 7.9 & 14.2 \\
\hline Cercopithecinae & Papio ursinus & 21.6 & 7.4 & 15.1 \\
\hline Cercopithecinae & Papio ursinus & 29.9 & 7.7 & 14.6 \\
\hline Cercopithecinae & Papio ursinus & 32.9 & 7.6 & 13.9 \\
\hline Cercopithecinae & Papio ursinus & 27.7 & 8.0 & 14.9 \\
\hline Cercopithecinae & Papio ursinus & 31.7 & 7.7 & 13.0 \\
\hline Cercopithecinae & Papio ursinus & 27.6 & 8.2 & 13.6 \\
\hline Cercopithecinae & Papio ursinus & 22.6 & 7.1 & 12.4 \\
\hline Cercopithecinae & Papio ursinus & 28.2 & 7.5 & 15.1 \\
\hline Cercopithecinae & Papio ursinus & 29.7 & 8.2 & 14. \\
\hline
\end{tabular}




\begin{tabular}{|c|c|c|c|c|}
\hline Cercopithecinae & Papio ursinus & 34.6 & 7.1 & 14.4 \\
\hline Cercopithecinae & Papio ursinus & 33.3 & 7.9 & 14.9 \\
\hline Cercopithecinae & Papio ursinus & 33.4 & 7.9 & 14.3 \\
\hline Cercopithecinae & Papio ursinus & 28.6 & 7.3 & 14.3 \\
\hline Cercopithecinae & Papio ursinus & 29.8 & 9.2 & 13.6 \\
\hline Cercopithecinae & Papio ursinus & 28.7 & 8.1 & 15.4 \\
\hline Cercopithecinae & Papio ursinus & 23.4 & 7.6 & 11.9 \\
\hline Cercopithecinae & Papio ursinus & 30.1 & 8.7 & 14.4 \\
\hline Cercopithecinae & Papio ursinus & 23.4 & 7.7 & 13.9 \\
\hline Cercopithecinae & Papio anubis & 32.3 & 15.4 & 16.1 \\
\hline Cercopithecinae & Papio angusticeps & 20.0 & 6.0 & 9.8 \\
\hline Cercopithecinae & Papio angusticeps & 22.0 & 6.4 & 10.1 \\
\hline Cercopithecinae & Papio angusticeps & 20.0 & 6.8 & 11.3 \\
\hline Cercopithecinae & Papio robinsoni & 20.0 & 7.0 & 12.5 \\
\hline Cercopithecinae & Papio angusticeps & 24.0 & 7.5 & 10.0 \\
\hline Cercopithecinae & Papio or Parapapio & 13.6 & 5.0 & 10.2 \\
\hline Cercopithecinae & Papio or Parapapio & 16.1 & 5.6 & 7.8 \\
\hline Cercopithecinae & Papio or Parapapio & 18.3 & 5.8 & 9.7 \\
\hline
\end{tabular}




\begin{tabular}{|c|c|c|c|c|}
\hline Cercopithecinae & Papio or Parapapio & 17.5 & 5.9 & 10.1 \\
\hline Cercopithecinae & Papio or Parapapio & 14.4 & 5.9 & 8.5 \\
\hline Cercopithecinae & $\begin{array}{c}\text { Papio or Procerco- } \\
\text { cebus }\end{array}$ & 18.1 & 6.2 & 8.9 \\
\hline Cercopithecinae & Papio or Parapapio & 9.3 & 6.0 & 8.4 \\
\hline Cercopithecinae & Parapapio ado & 11.5 & 5.8 & 10.0 \\
\hline Cercopithecinae & Parapapio ado & 15.1 & 8.3 & 12.3 \\
\hline Cercopithecinae & cf. Parapapio ado & 19.4 & 6.3 & 10.1 \\
\hline Cercopithecinae & cf. Parapapio ado & 16.7 & 6.8 & 10.6 \\
\hline Cercopithecinae & Parapapio jonesi & 14.8 & 5.9 & 8.8 \\
\hline Cercopithecinae & Parapapio jonesi & 21.0 & 6.3 & 10.5 \\
\hline Cercopithecinae & Parapapio jonesi & 20.0 & 6.4 & 8.8 \\
\hline Cercopithecinae & Parapapio jonesi & 20.5 & 5.8 & 8.9 \\
\hline Cercopithecinae & Parapapio jonesi & 17.9 & 6.7 & 11.6 \\
\hline Cercopithecinae & Parapapio jonesi & 23.0 & 7.8 & 10.1 \\
\hline Cercopithecinae & Parapapio jonesi & 17.6 & 6.2 & 10.5 \\
\hline Cercopithecinae & Parapapio broomi & 22.0 & 6.9 & 10.7 \\
\hline Cercopithecinae & Parapapio broomi & 16.3 & 7.2 & 1 \\
\hline
\end{tabular}




\begin{tabular}{|c|c|c|c|c|}
\hline Cercopithecinae & Parapapio broomi & 16.2 & 6.7 & 9.8 \\
\hline Cercopithecinae & Parapapio broomi & 19.0 & 7.0 & 9.2 \\
\hline Cercopithecinae & Parapapio broomi & 17.0 & 6.5 & 10.1 \\
\hline Cercopithecinae & Parapapio broomi & 17.5 & 6.4 & 10.5 \\
\hline Cercopithecinae & Parapapio broomi & 22.7 & 7.3 & 9.7 \\
\hline Cercopithecinae & Parapapio broomi & 18.0 & 6.5 & 9.7 \\
\hline Cercopithecinae & Parapapio whitei & 21.7 & 8.1 & 13.1 \\
\hline Cercopithecinae & $\begin{array}{c}\text { Parapapio lothaga- } \\
\text { mensis }\end{array}$ & - & 6.0 & $>9.8$ \\
\hline Cercopithecinae & $\begin{array}{c}\text { Parapapio lothaga- } \\
\text { mensis }\end{array}$ & - & 5.3 & 8.7 \\
\hline Cercopithecinae & $\begin{array}{c}\text { Parapapio lothaga- } \\
\text { mensis }\end{array}$ & - & 5.4 & 8.5 \\
\hline Cercopithecinae & $\begin{array}{c}\text { Parapapio lothaga- } \\
\text { mensis }\end{array}$ & - & 5.5 & 8.6 \\
\hline Cercopithecinae & $\begin{array}{c}\text { Parapapio lothaga- } \\
\text { mensis }\end{array}$ & - & $<5.8$ & (9.5) \\
\hline Cercopithecinae & $\begin{array}{c}\text { cf. Procercocebus } \\
\text { antiquus }\end{array}$ & 33.6 & 9.7 & 12.3 \\
\hline Cercopithecinae & $\begin{array}{l}\text { Theropithecus } \\
\text { gelada }\end{array}$ & 27.4 & 6.6 & 12.3 \\
\hline Cercopithecinae & Theropithecus & 21.4 & 7.3 & 9 \\
\hline
\end{tabular}




\begin{tabular}{|c|c|c|c|c|}
\hline Cercopithecinae & $\begin{array}{c}\text { Theropithecus } \\
\text { gelada }\end{array}$ & 23.9 & 8.1 & 6.9 \\
\hline Cercopithecinae & $\begin{array}{c}\text { Theropithecus } \\
\text { gelada }\end{array}$ & 21.9 & 7.8 & 12.2 \\
\hline Cercopithecinae & $\begin{array}{c}\text { Theropithecus } \\
\text { gelada }\end{array}$ & 25.9 & 11.5 & 7.6 \\
\hline Cercopithecinae & $\begin{array}{c}\text { Theropithecus } \\
\text { gelada }\end{array}$ & 21.2 & 7.4 & 10.7 \\
\hline Cercopithecinae & $\begin{array}{c}\text { Theropithecus } \\
\text { gelada }\end{array}$ & 27.3 & 8.0 & 11.6 \\
\hline Cercopithecinae & $\begin{array}{c}\text { Theropithecus } \\
\text { gelada }\end{array}$ & 26.4 & 8.1 & 12.2 \\
\hline Cercopithecinae & $\begin{array}{c}\text { Theropithecus } \\
\text { gelada }\end{array}$ & 22.4 & 6.6 & 10.9 \\
\hline Cercopithecinae & $\begin{array}{c}\text { Theropithecus os- } \\
\text { waldi leakeyi }\end{array}$ & 23.4 & 11.0 & 14.7 \\
\hline Cercopithecinae & $\begin{array}{c}\text { Theropithecus os- } \\
\text { waldi leakeyi }\end{array}$ & 20.3 & 10.0 & 14.3 \\
\hline Cercopithecinae & $\begin{array}{c}\text { Theropithecus os- } \\
\text { waldi leakeyi }\end{array}$ & 20.0 & 10.5 & 13.9 \\
\hline Cercopithecinae & $\begin{array}{c}\text { Theropithecus os- } \\
\text { waldi leakeyi }\end{array}$ & 31.5 & 8.5 & 14.8 \\
\hline Cercopithecinae & Theropithecus os- & 23.9 & 13.7 & 18.1 \\
\hline
\end{tabular}




\begin{tabular}{|c|c|c|c|c|}
\hline Cercopithecinae & $\begin{array}{c}\text { Theropithecus os- } \\
\text { waldi leakeyi }\end{array}$ & 29.0 & 11.0 & 19.7 \\
\hline Cercopithecinae & $\begin{array}{c}\text { Theropithecus os- } \\
\text { waldi darti }\end{array}$ & 42.0 & 11.2 & 15.4 \\
\hline Cercopithecinae & $\begin{array}{c}\text { Theropithecus os- } \\
\text { waldi darti }\end{array}$ & 25.0 & 7.3 & 12.6 \\
\hline Cercopithecinae & $\begin{array}{c}\text { Theropithecus } \\
\text { baringensis }\end{array}$ & 22.5 & 8.5 & 15.0 \\
\hline Colobinae & $\begin{array}{c}\text { Colobinae sp. A } \\
\text { Lothagam }\end{array}$ & - & 4.5 & 6.5 \\
\hline Colobinae & $\begin{array}{c}\text { Colobinae sp. B } \\
\text { Lothagam }\end{array}$ & - & 6.2 & 10.3 \\
\hline Colobinae & $\begin{array}{l}\text { Colobinae sp. B } \\
\text { Lothagam }\end{array}$ & - & 6.1 & 10.1 \\
\hline Colobinae & Colobus guereza & 14.6 & 5.1 & 8.0 \\
\hline Colobinae & Colobus guereza & 17.4 & 5.1 & 7.7 \\
\hline Colobinae & Colobus guereza & 15.0 & 5.5 & 8.5 \\
\hline Colobinae & Colobus satanas & 12.5 & 5.0 & 6.4 \\
\hline Colobinae & Colobus sp. & 5.2 & 3.5 & 5.7 \\
\hline Colobinae & $\begin{array}{c}\text { Piliocolobus rufomi- } \\
\text { tratus }\end{array}$ & 15.3 & 7.0 & 9.4 \\
\hline Colobinae & Piliocolobus rufomi- & 16.2 & 6.7 & 9.2 \\
\hline
\end{tabular}




\begin{tabular}{|c|c|c|c|c|}
\hline Colobinae & $\begin{array}{c}\text { Piliocolobus rufomi- } \\
\text { tratus }\end{array}$ & 15.5 & 6.9 & 9.7 \\
\hline Colobinae & $\begin{array}{c}\text { Piliocolobus rufomi- } \\
\text { tratus }\end{array}$ & 17.5 & 5.4 & 8.8 \\
\hline Colobinae & $\begin{array}{c}\text { Piliocolobus rufomi- } \\
\text { tratus }\end{array}$ & 16.4 & 5.7 & 8.2 \\
\hline Colobinae & $\begin{array}{c}\text { Piliocolobus rufomi- } \\
\text { tratus }\end{array}$ & 9.8 & 6.1 & 8.4 \\
\hline Colobinae & $\begin{array}{c}\text { Piliocolobus rufomi- } \\
\text { tratus }\end{array}$ & 15.2 & 5.0 & 7.3 \\
\hline Colobinae & $\begin{array}{c}\text { Piliocolobus rufomi- } \\
\text { tratus }\end{array}$ & 16.2 & 5.8 & 8.6 \\
\hline Colobinae & $\begin{array}{c}\text { Piliocolobus rufomi- } \\
\text { tratus }\end{array}$ & 15.5 & 4.8 & 7.6 \\
\hline Colobinae & $\begin{array}{c}\text { Piliocolobus rufomi- } \\
\text { tratus }\end{array}$ & 14.3 & 6.4 & 8.8 \\
\hline Colobinae & Piliocolobus epieni & 5.5 & 3.0 & 4.6 \\
\hline Colobinae & $\begin{array}{c}\text { Kuseracolobus } \\
\text { aramisi }\end{array}$ & 17.4 & 5.4 & 9.3 \\
\hline Colobinae & $\begin{array}{c}\text { Kuseracolobus } \\
\text { aramisi }\end{array}$ & 16.6 & 5.3 & 8.4 \\
\hline Colobinae & Nasalis larvatus & 16.1 & 5.2 & 7.5 \\
\hline Colobinae & Nasalis larvatus & 6.0 & 3.7 & 5.5 \\
\hline
\end{tabular}




\begin{tabular}{|c|c|c|c|c|}
\hline Colobinae & Nasalis larvatus & 15.9 & 5.7 & 6.4 \\
\hline Colobinae & Nasalis larvatus & 18.4 & 6.4 & 6.5 \\
\hline Colobinae & Nasalis larvatus & 13.2 & 4.8 & 6.0 \\
\hline Colobinae & Nasalis larvatus & 11.2 & 4.9 & 7.1 \\
\hline Colobinae & Nasalis larvatus & 11.9 & 4.5 & 6.5 \\
\hline Colobinae & Nasalis larvatus & 11.9 & 3.5 & 7.0 \\
\hline Colobinae & Simias concolor & 8.0 & 4.8 & 5.7 \\
\hline Colobinae & Simias concolor & 9.3 & 4.9 & 4.6 \\
\hline Colobinae & Simias concolor & 10.1 & 5.2 & 5.9 \\
\hline Colobinae & Simias concolor & 11.9 & 5.0 & 5.5 \\
\hline Colobinae & Simias concolor & 11.5 & 4.5 & 5.8 \\
\hline Colobinae & $\begin{array}{c}\text { Rhinopithecus rox- } \\
\text { ellana }\end{array}$ & 16.4 & 6.1 & 7.4 \\
\hline Colobinae & $\begin{array}{c}\text { Rhinopithecus lan- } \\
\text { tianensis }\end{array}$ & 12.8 & 5.8 & 9.0 \\
\hline Colobinae & Rhinopithecus bieti & 16.2 & 8.5 & 8.6 \\
\hline Colobinae & $\begin{array}{l}\text { Rhinopithecus bre- } \\
\text { lichi }\end{array}$ & 11.5 & 7.3 & 8.1 \\
\hline Colobinae & Presbytis thomasi & 11.7 & 4.1 & 5.7 \\
\hline
\end{tabular}




\begin{tabular}{|c|c|c|c|c|}
\hline Colobinae & Presbytis rubicunda & 10.6 & 4.1 & 5.7 \\
\hline Colobinae & Presbytis rubicunda & 10.2 & 4.3 & 5.1 \\
\hline Colobinae & Presbytis rubicunda & 5.9 & 4.0 & 4.5 \\
\hline Colobinae & Presbytis rubicunda & 5.9 & 4.2 & 4.7 \\
\hline Colobinae & Presbytis rubicunda & 10.0 & 4.0 & 5.7 \\
\hline Colobinae & Presbytis siamensis & 11.4 & 4.4 & 5.3 \\
\hline Colobinae & Presbytis siamensis & 10.7 & 4.7 & 5.7 \\
\hline Colobinae & Presbytis siamensis & 10.5 & 3.8 & 4.9 \\
\hline Colobinae & Presbytis siamensis & 11.6 & 3.7 & 4.7 \\
\hline Colobinae & Presbytis siamensis & 9.1 & 4.2 & 5.4 \\
\hline Colobinae & Presbytis siamensis & 9.6 & 3.3 & 5.0 \\
\hline Colobinae & Presbytis siamensis & 5.7 & 3.2 & 5.0 \\
\hline Colobinae & Presbytis potenziani & 13.1 & 4.0 & 5.9 \\
\hline Colobinae & Presbytis potenziani & 7.4 & 3.0 & 5.8 \\
\hline Colobinae & Presbytis potenziani & 9.6 & 3.1 & 5.2 \\
\hline Colobinae & Presbytis potenziani & 12.3 & 4.2 & 5.6 \\
\hline Colobinae & $\begin{array}{c}\text { Semnopithecus en- } \\
\text { tellus }\end{array}$ & 17.0 & 6.5 & 9.2 \\
\hline Colobinae & Semnopithecus en- & 14.4 & 5.8 & 7.6 \\
\hline
\end{tabular}




\begin{tabular}{|c|c|c|c|c|}
\hline Colobinae & $\begin{array}{c}\text { Semnopithecus en- } \\
\text { tellus }\end{array}$ & 16.0 & 5.6 & 7.0 \\
\hline Colobinae & Kasi johnii & 16.8 & 5.4 & 7.1 \\
\hline Colobinae & Kasi johnii & 11.6 & 4.7 & 6.6 \\
\hline Colobinae & Kasi johnii & 12.1 & 4.9 & 7.3 \\
\hline Colobinae & Kasi johnii & 13.9 & 4.2 & 6.9 \\
\hline Colobinae & $\begin{array}{c}\text { Trachypithecus ob- } \\
\text { scurus }\end{array}$ & 12.3 & 4.5 & 6.8 \\
\hline Colobinae & $\begin{array}{c}\text { Trachypithecus ob- } \\
\text { scurus }\end{array}$ & 12.4 & 4.0 & 6.1 \\
\hline Colobinae & $\begin{array}{c}\text { Trachypithecus } \\
\text { pileatus }\end{array}$ & 12.6 & 7.1 & 7.1 \\
\hline Colobinae & $\begin{array}{l}\text { Trachypithecus } \\
\text { pileatus }\end{array}$ & 16.8 & 5.7 & 7.7 \\
\hline Colobinae & $\begin{array}{l}\text { Trachypithecus } \\
\text { pileatus }\end{array}$ & 15.5 & 4.8 & 7.7 \\
\hline Colobinae & $\begin{array}{c}\text { Trachypithecus } \\
\text { pileatus }\end{array}$ & 13.0 & 5.1 & 7.3 \\
\hline Colobinae & $\begin{array}{l}\text { Trachypithecus } \\
\text { pileatus }\end{array}$ & 14.5 & 5.5 & 7.2 \\
\hline Colobinae & $\begin{array}{c}\text { Trachypithecus } \\
\text { pileatus }\end{array}$ & 6.7 & 3.4 & 5.8 \\
\hline
\end{tabular}




\begin{tabular}{|c|c|c|c|c|}
\hline Colobinae & $\begin{array}{c}\text { Trachypithecus } \\
\text { pileatus }\end{array}$ & 16.8 & 4.9 & 7.7 \\
\hline Colobinae & $\begin{array}{c}\text { Trachypithecus } \\
\text { pileatus }\end{array}$ & 12.4 & 4.5 & 5.5 \\
\hline Colobinae & $\begin{array}{c}\text { Trachypithecus } \\
\text { pileatus }\end{array}$ & 3.8 & 2.4 & 3.5 \\
\hline Colobinae & $\begin{array}{c}\text { Trachypithecus } \\
\text { pileatus }\end{array}$ & 11.2 & 4.2 & 5.5 \\
\hline Colobinae & $\begin{array}{c}\text { Trachypithecus } \\
\text { pileatus }\end{array}$ & 12.4 & 4.5 & 5.5 \\
\hline Colobinae & $\begin{array}{c}\text { Trachypithecus } \\
\text { pileatus }\end{array}$ & 12.3 & 5.7 & 9.2 \\
\hline Colobinae & $\begin{array}{l}\text { Paracolobus } \\
\text { chemeroni }\end{array}$ & 24.0 & 7.7 & 12.7 \\
\hline Colobinae & Rhinocolobus sp. & 20.5 & 6.1 & 10.9 \\
\hline Colobinae & $\begin{array}{l}\text { Rhinocolobus } \\
\text { turkanaensis }\end{array}$ & 23.0 & 6.5 & 12.0 \\
\hline Colobinae & $\begin{array}{l}\text { cf. Cercopithecoides } \\
\text { kimeui }\end{array}$ & 17.7 & 5.2 & 9.3 \\
\hline Colobinae & $\begin{array}{l}\text { Paracolobus enko- } \\
\text { rikae }\end{array}$ & - & 5.4 & 7.7 \\
\hline Indet. & $\begin{array}{l}\text { Chorora lower ca- } \\
\text { nine CHO-BT } 123\end{array}$ & - & 4.7 & 6.4 \\
\hline Indet. & Ngorora lower ca- & - & 5.0 & 7.5 \\
\hline
\end{tabular}


nine KNM-TH 23144

Indet.

AUH 35

16.4

5.1

8.4

Notes: All extant and fossil data for cercopithecines and colobines taken from the PRIMO online database, access courtesy of Eric Delson. Measurements for AUH 35 taken from Hill and Gundling (1999). Note that "width" in Hill and Gundling (1999) corresponds to "length" in PRIMO, and "length" in Hill and Gundling (1999) corresponds to "width" in PRIMO. All measurements are aligned homologously in this table. Ngorora data from Hill et al. (2002), Lothagam data from Leakey et al. (2003), data for Lemudong'o from Hlusko (2007), data for Chorora from Suwa et al. (2015). 
Fig 13.1

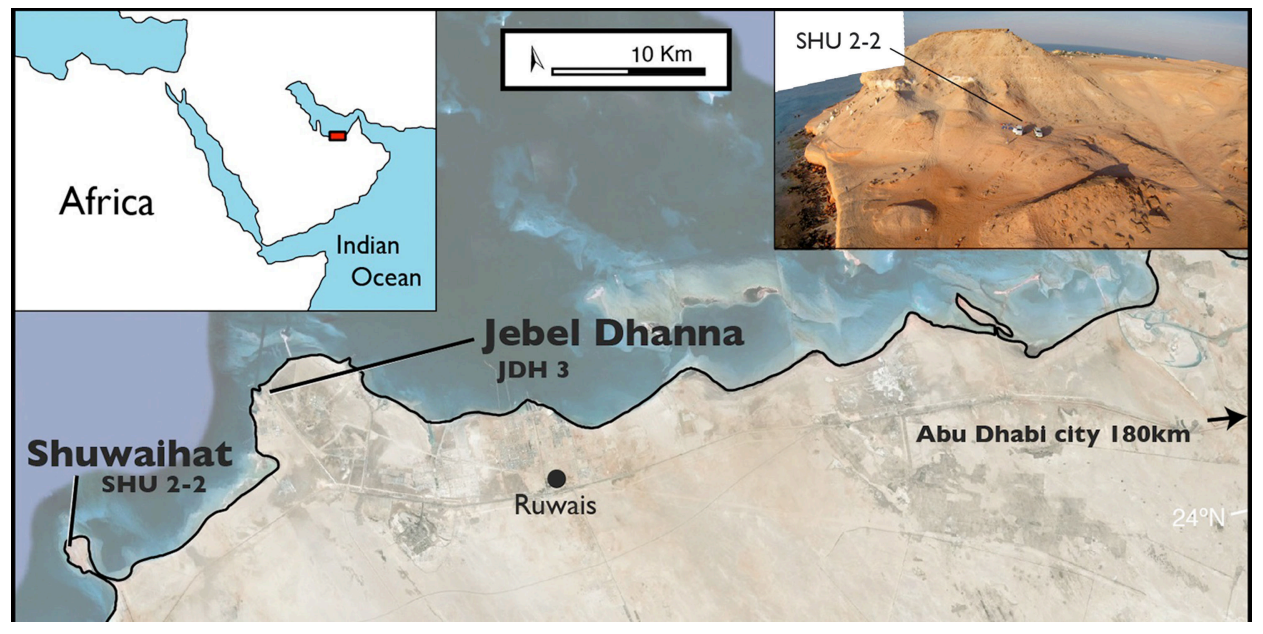


Fig 13.2

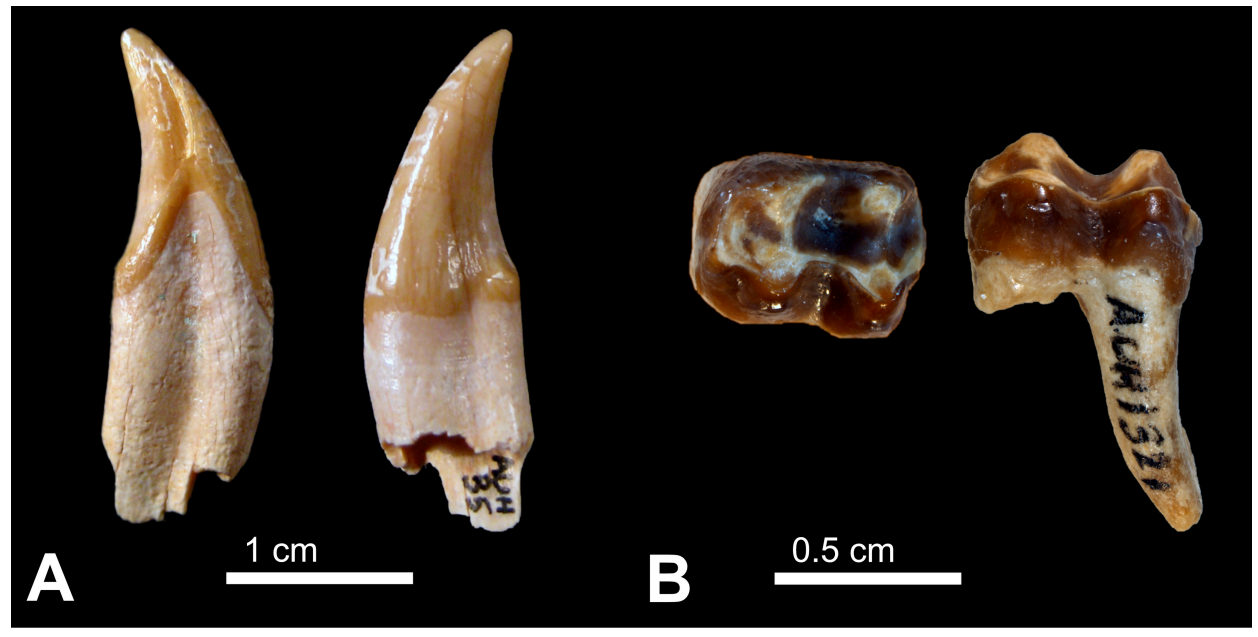


Fig 13.3

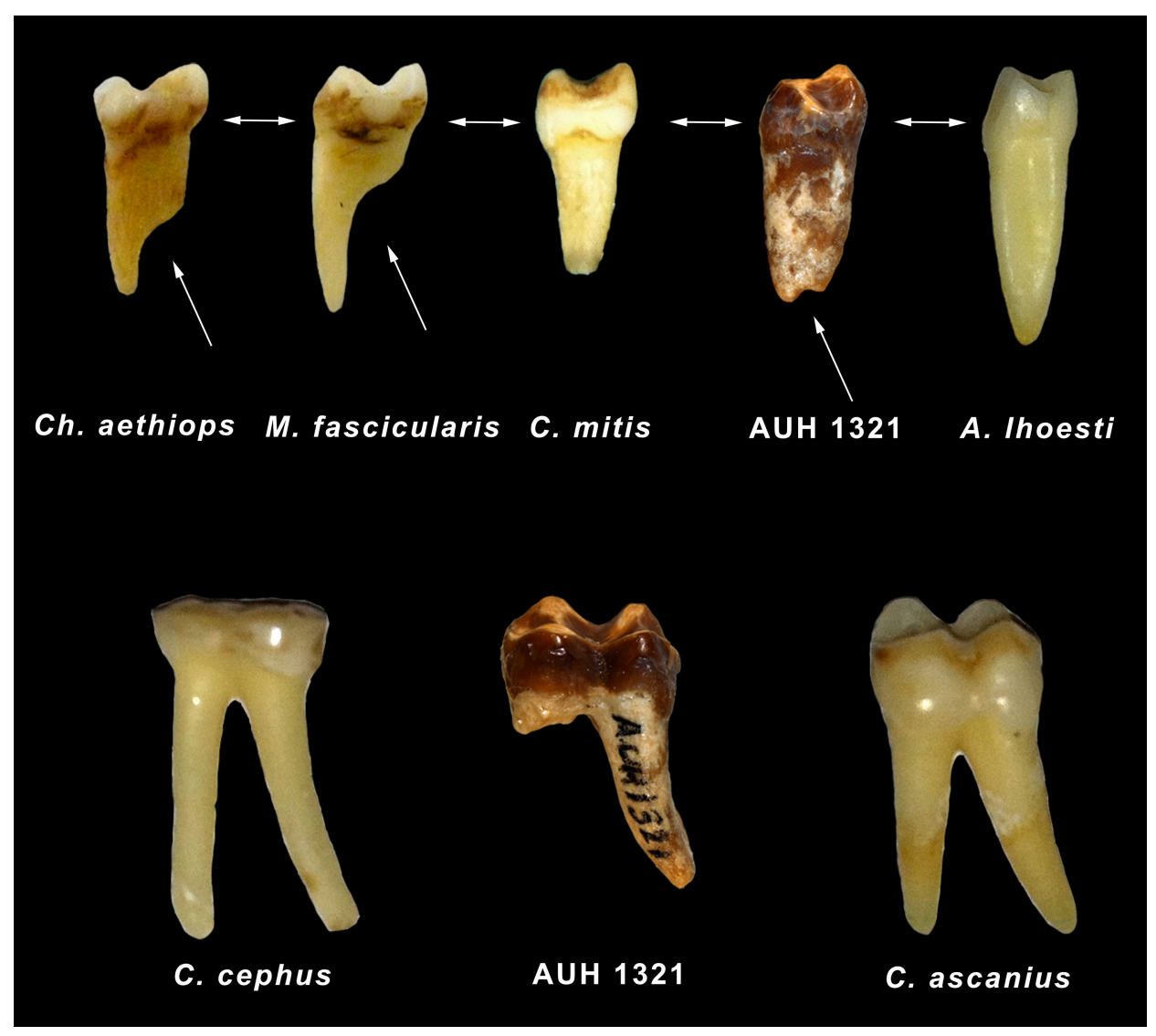


Fig 13.4
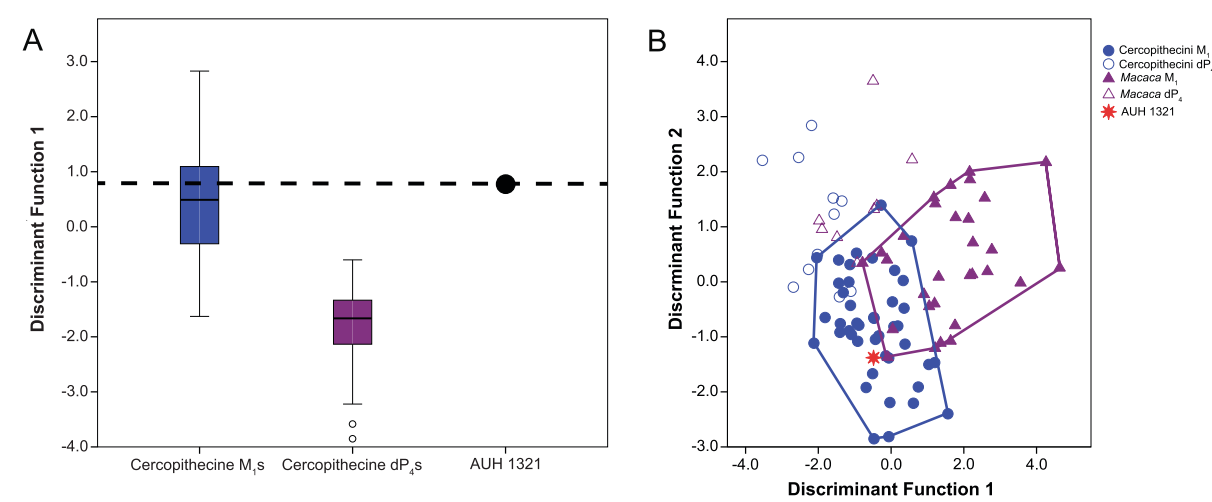
Fig 13.5
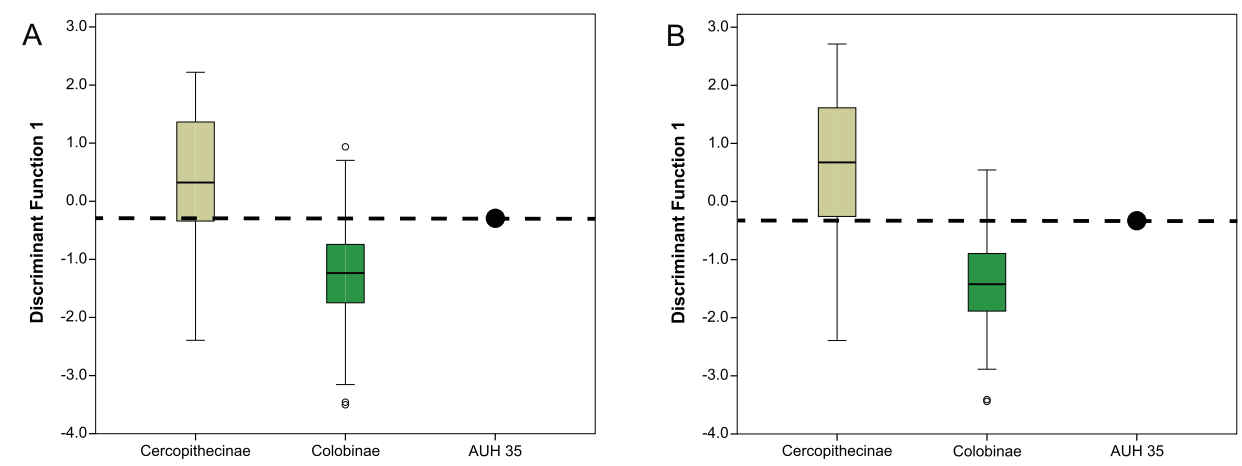
Fig 13.6

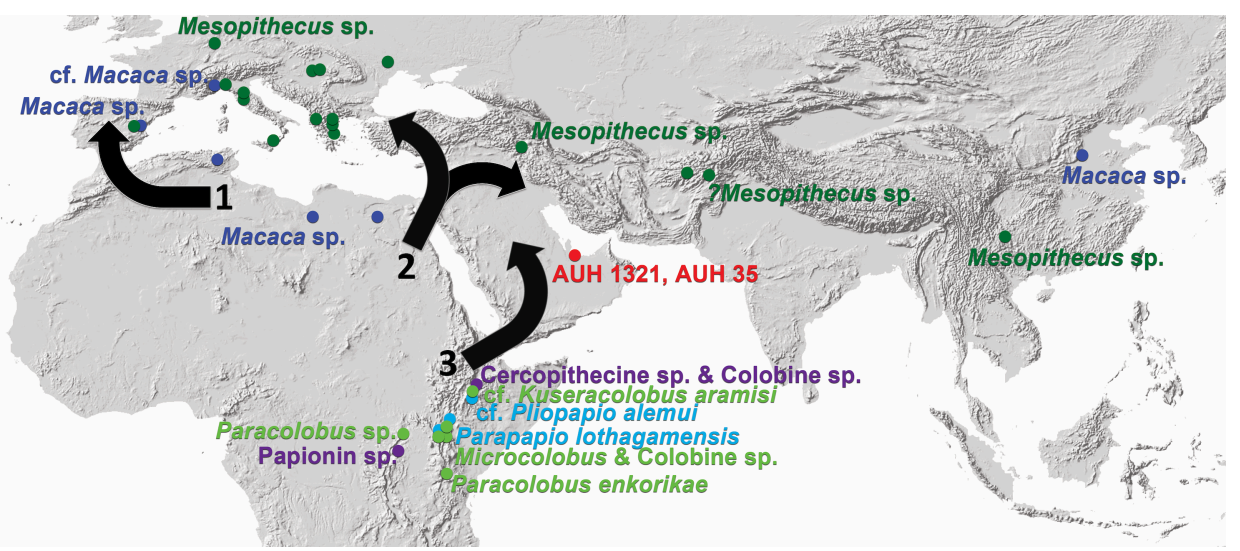

